\title{
Foreign acquisitions of Italian medium-sized companies from $\mathrm{MNEs}^{1}$
}

\author{
Riccardo Resciniti - Gabriele Barbaresco - Giulio Maggiore \\ Michela Matarazzo
}

\begin{abstract}
Purpose of the paper: Italy is one of the most attractive European destinations for FDI inflows worldwide. It has witnessed a rapid increase in mergers and acquisitions, to the point of overcoming the EU 15 mean in the years 2008-2013 (with the exception of 2012) (UNCTAD, 2014). The question of whether governments should foster foreign take-overs is crucial, since the Italian economy has been traditionally founded on "national champions".

The purpose of the paper is to present a broader research project that aims at investigating (at firms' level) the performance differences of all the mid-sized foreigncontrolled firms, compared with the non acquired firms in the manufacturing industry.

Methodology: the paper analyzes firms acquired in the period between 1999 and 2009 by using data from Mediobanca Research Department.

Findings: first results in terms of composition of the acquired mid-sized companies are shown.

Practical implications: the paper defines the different perspectives of analysis describing the managerial effects of foreign acquisitions on the acquired firms, the MNE acquirers, and the target country with respect to the industrial development, the employment and the supply chains of the territory.

Originality of the paper: the study uses Mediobanca Research Department database for the first time in order to investigate the topic of cross border acquisitions.
\end{abstract}

Key words: cross-border acquisitions; mid-sized target companies; Made in Italy

\section{Research significance}

The ongoing success of "Made in Italy" on foreign markets has recently lead to an inverse internationalization process, where medium-sized firms - formerly conquerors - become "preys". As a target country, Italy has

$1 \quad$ The paper derives from the work "Le acquisizioni dallestero delle medie imprese italiane: l'impatto sulle performance" presented by Prof. Resciniti and by Dr. Barbaresco at XXVI Sinergie Annual Conference, during the Plenary Session.

Prof. Giulio Maggiore and Prof. Michela Matarazzo contributed to the further development of the paper.

This paper is the result of the joint effort of the authors. Nevertheless, section 1 was written by Riccardo Resciniti, section 2 by Giulio Maggiore, section 3 by Gabriele Barbaresco, section 4 by Michela Matarazzo and section 5 by all the authors. 
Sinergie Vol. 33, N. 98, 2015

witnessed a rapid increase in inward FDI, mainly through mergers and acquisitions in absolute terms: 825 Italian acquired firms from 2010 to 2014, for a value of $32.6 \mathrm{mld} €$ (Unctad 2014). As a result, in the last years the share of foreign ownerships in the total population of firms has grown in Italy. Well-known former Italian-owned firms have changed ownership and are currently foreign-owned: for example, within food \& beverage, Parmalat, Bertolli, Fiorucci, Gancia, Findus; within fashion, Brioni, Valentino, Bulgari, Loro Piana; within personal and household goods, Bormioli, Richard Ginori, Poltrona Frau; and within other manufacturing sectors, Lamborghini, Ducati and Atala. The increase in foreign ownership has given rise to mixed feelings in the Italian public debate, since Italy has traditionally tended to discourage foreign takeovers, but has rather fostered the emergence of "national champions". Some fear that foreign acquisitions will lead to job losses and have a detrimental effect on target firms' performances since multinationals (MNEs) are less committed to the host economy and are more likely to relocate production among affiliates in different countries. The new foreign owner may want to change the size and composition of the labor force or employment conditions. On the other side, consistently with FDI theory, MNEs may bring new capital, new technology, brand reputation, management practices and market access opportunities. In receipt of such assets, the multinational affiliate enjoys a productivity advantage over its less fortunate host country rivals, thus strengthening overall competitiveness in the economy. The qualitative profile of this process is even more important, in that it responds to what literature calls "cherry picking" approach as opposed to "lemon picking". This means that foreign multinationals choose "preys" with the best performances rather than minor firms. The acquisition objective is not so much a matter of restructuring or giving a new impetus to distressed firms, as to absorb firms already well-structured, both on a commercial and management level, sometimes even financially solid.

Medium-sized firms are often an acquisition target, thanks to the gap between their positive performances and their small size (and capitals) which makes their acquisition particularly convenient. Thus, from 1999 to 2009,143 Italian medium-sized firms were acquired by foreign groups (data from Mediobanca). Several firms from the above-mentioned "emerging treasury" of our country were acquired by big foreign players.

The phenomenon is a typical expression of globalization, which is strongly drawn by the concentration of supply. It is particularly relevant for our country and has to be analyzed by taking into account the different involved stakeholders: the big acquiring firm, the acquired medium-sized firms, the business family, the State and the territory. Although effects are strongly linked to each other and cannot be easily separated, they can be schematized according to the stakeholder typology.

Accordingly, our research project asks the following research question: Are there differences in the target-firm performance post-acquisition compared with purely domestic firms (non-acquired)? In order to shed light on these issues, in this paper we investigate the effects of cross border 
acquisitions on the performance of target firms in terms of several accounting measures (labor productivity, employment, wages, Roe, export turnover, etc.).

This paper presents the first results of the above mentioned research in terms of composition of the acquired mid-sized companies. It is structured as follows. In section 2 we look at the relevant theoretical concepts of existing literature. Section 3 describes the first results, section 4 focuses on future research by illustrating hypothesis and methodology to test them, while section 5 concludes.

\section{Advantages of cross border acquisitions from different points of view}

There is a variety of studies on cross-border acquisitions. They can be distinguished according to the analyzed stakeholders' perspective and the effects on them.

Above all, large groups acquire minor firms to:

- enter a foreign market rapidly and directly. Acquisition is preferred to greenfield investment, which can be subject to the liability of newness (Caves, 1996) and foreignness (Luo, 1999), particularly when the acquirer has a high level of experience and the investment is significant (Harzing, 2002), when there are entry barriers to export (customs policies and duties) or in case of market potential and high quality inputs (Demirbag et al., 2008);

- quickly get hold of the target firm's tangible and intangible assets: whether it is technological and manufacturing know-how, licenses and patents, which is the case of technology-grafting acquisitions (Desyllas e Hughes, 2008), management skills (managerial learning, Engelhard and Nägele, 2003) or downstream assets (brands, salesforce) (Anand and Delios, 2002).

For the acquired medium-sized firms, becoming part of a multinational can:

- open to new markets or allow a better access to their existing markets (Chen, 2011; Chari et al., 2012), thanks to big groups' presence in foreign countries. "Made in Italy" products benefit from their inclusion in the multinationals' product range, distribution channels, and more in general networks, particularly, when it comes to attractive but less accessible markets;

- have a "disciplinary" effect imposed by the new society, which can improve or eliminate management inefficiencies in the acquired firm, or increase their productivity, investments in $\mathrm{R} \& \mathrm{D}$, average wage and export capacity (Girma and Görg, 2007; Heyman et al., 2007, Bertrand and Zitouna, 2008; Weche Gelübcke, 2013);

- strengthen their position in relation to suppliers and customers, thanks to the new owner's better market potential, which can turn useful in trade relations also in terms of payment periods (those from clients are reduced while those to suppliers are increased);

- increase investment and survival potentials (McGuckin and Nguyen, 2001) increase organizational, technological, managerial and commercial spillovers (Piscitello e Rabbiosi, 2005).

In the public perspective concerning the FDI destination country,
Riccardo Resciniti

Gabriele Barbaresco

Giulio Maggiore

Michela Matarazzo

Foreign acquisitions of

talian medium-sized

companies from MNEs

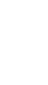


sinergie Vol. 33, N. 98, 2015

its national industrial system and the acquired firm's region of origin, acquisitions bring new capitals from abroad and organizational, technological, managerial and commercial spillovers through contact with a new business reality. However, there can also be dangers and risks, such as:

- impoverishing the national industrial heritage, when acquired firms lose their independence becoming mere branches of foreign groups. Acquired firms are often incorporated, immediately or in a few years, thus disappearing as autonomous entities (Hopkins, 2002; UNCTAD, 2000; Balsvik and Haller, 2010; Damijan et al., 2014);

- being deprived of the profits from acquired activities, as very often in multinational holdings the profits of a local subsidiary are transferred to the headquarter or used to compensate losses due to other subsidiaries (Hopkins, 1999; UNCTAD, 2000; Balsvik and Haller, 2010; Damijan et al., 2014);

- suffering cutbacks in employment levels (Conyon et al., 2002);

- closing or marginalizing domestic production sites of the target firms also through their relocation abroad, mostly to areas with low cost production factors;

- draining local supply chains and networks because of the replacement of local suppliers and partners, as well as of funding banks, with foreign ones.

It is rather difficult to determine the effects on the payment balance in the acquired firm's country. They concern capital inflows (investments related to the acquisition) and outflows in the current account (mostly profits towards the holding group), as well as implications for the trade balance due to the new import/export logic, because of the relocation of production sites and the changes in supply channels and customers in Italy and abroad.

The effects for the owner's family selling off their business are complex in that they concern economical and psychological aspects, not just related to family interests. Undoubtedly a transfer brings significant incomes, which is why those who sell obtain massive sums of capital; yet, this can be dangerous in terms of entrepreneurship. Such capitals can be re-invested by the owner's family in new - often smaller - businesses, but also in other non-productive assets (real estate, finance, etc.). For the national economy this means the interruption of the positive mechanism of transition from one generation of managers to the next in the owners' family: only sometimes family members keep their roles in the board of directors or as managers ${ }^{2}$.

\section{The mid-sized companies acquired from MNEs: composition by industry, country of origin and year of acquisition}

In this study, we have focused on acquisitions of all mid-sized firms in Made in Italy industries. This is because they are particularly attractive

"Their job will be different: to preserve a financial heritage so that it gives highest yealds by the lowest possible risk. A job that is far from what had generated health" (Guiso, 2014). 
(Coltorti et al., 2013) due to their competitive strength which resides in the diversification of their products, most of which may be classified under the umbrella of Italian style, their managerial and entrepreneurial governance styles, structure and flexibility, international development (Matarazzo, 2012) Riccardo Resciniti Gabriele Barbaresco Giulio Maggiore Michela Matarazzo Foreign acquisitions of Italian medium-sized and effective niche strategies (figure 1). The sample was extracted from the Mediobanca Research Department database.

Fig. 1: Manufacturing: medium versus large firms

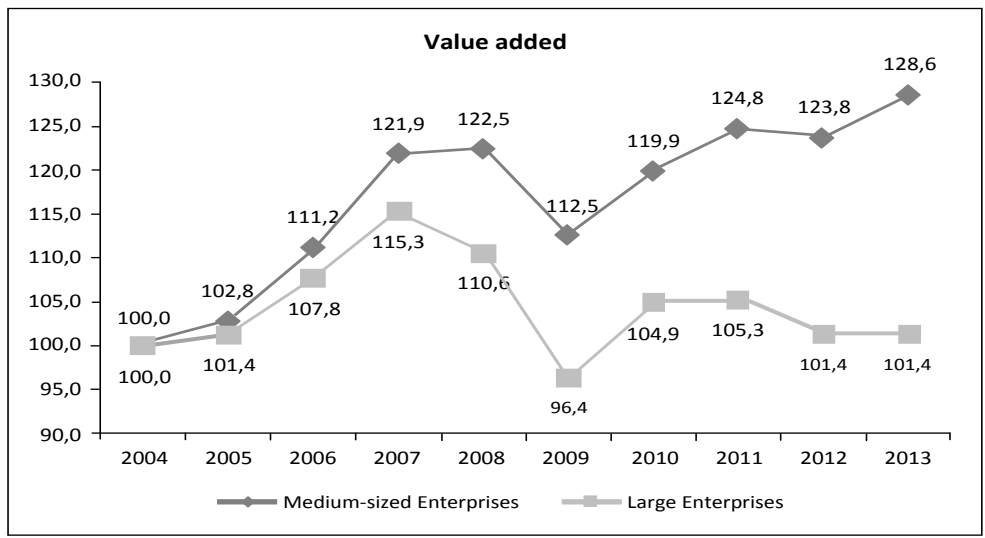

Source: Mediobanca; Mediobanca-Unioncamere

The selection procedure of the medium-sized firms taken over by foreign ownership concerned the period 1999-2009 and shares higher than 50\% of the share capital, or with lower share where there is transfer of management powers (table 1).

Tab. 1: Number of firms by year

\begin{tabular}{|c|c|}
\hline Year & N. of firms \\
\hline 1999 & 3,606 \\
\hline 2000 & 3,972 \\
\hline 2001 & 4,106 \\
\hline 2002 & 4,100 \\
\hline 2003 & 4,072 \\
\hline 2004 & 4,152 \\
\hline 2005 & 4,208 \\
\hline 2006 & 4,477 \\
\hline 2007 & 4,677 \\
\hline 2008 & 4,092 \\
\hline 2009 & 3,332 \\
\hline
\end{tabular}

Source: Our elaboration on Mediobanca database

From now on, the year when the above-mentioned limit was overcome is marked as "t time". Thus, a database of 143 Italian firms was identified (the "identified database"). Most of the target firms is located in the North 
Sinergie Vol. 33, N. 98, 2015

East (47.5\%) and North West (42\%), the remaining part (10.5\%) in the rest of Italy, again divided into North East-Center (6.3\%) and CenterSouth-Isles (4.2\%). In terms of product sectors, $49,6 \%$ of the acquired firms comes from the engineering sector, $18.2 \%$ from the chemicalpharmaceutical sector, $14.7 \%$ from the household and personal products sector and $9.8 \%$ from the food sector. Other sectors such as publishing $(3.5 \%)$, steel $(3.5 \%)$, and other manufacturing industries have minor significance (figure 2). The dominance of engineering and pharmaceutics seems consistent with the sectors where the foreign ownership in Italy has reached the highest levels of profitability and efficiency.

Acquiring firms mostly come from the 28 UE countries (63.6\%), $12.6 \%$ of which from the UK, $11.2 \%$ from France, 9.1\% from the Netherlands and $8.4 \%$ from Germany; $21.7 \%$ of the investors is located in the United States. Almost all of the acquisitions (94.4\%) were made by developed economies, whereas emerging and developing countries (5.6\% in all) only had a marginal role (table 2).

Fig. 2: Composition of the acquired mid-sized companies by industry Source: Our elaboration on Mediobanca database

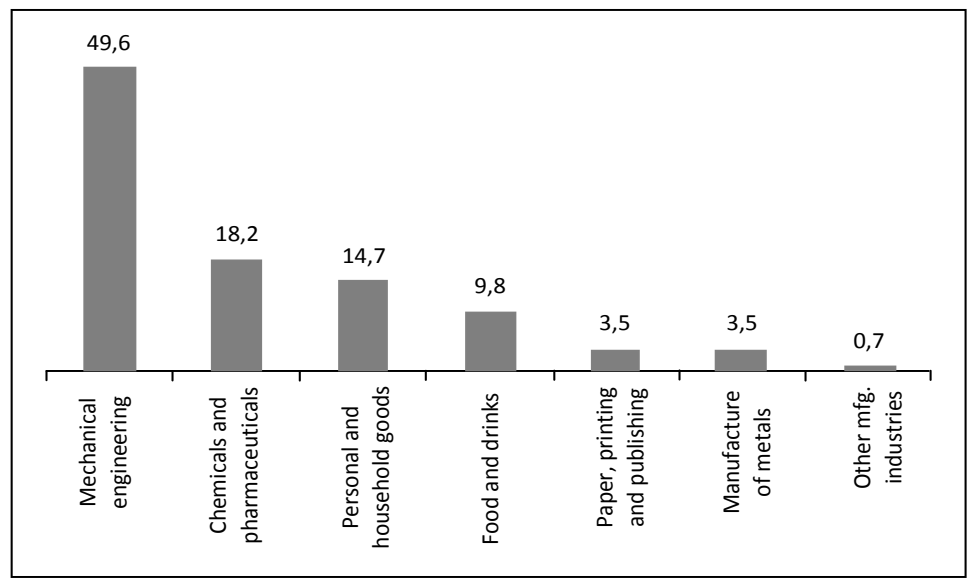

We have tried to reconstruct a continuous sequence of nine annual budgets of the 143 identified firms: four years pre-acquisition (from $\mathrm{t}-4$ to $t-1$ ), four years post-acquisition (from $t+1$ to $t+4$ ) and year of acquisition. The requirement of an uninterrupted series of budgets has reduced the database to an amount of 79 firms (55.2\% of the total amount) for which uninterrupted budgets are available for the nine years concerned (from $\mathrm{t}-4$ to $\mathrm{t}+4)$.

Acquiring firms mostly come from the $28 \mathrm{UE}$ countries (63.6\%), $12.6 \%$ of which from the UK, $11.2 \%$ from France, 9.1\% from the Netherlands and $8.4 \%$ from Germany; $21.7 \%$ of the investors is located in the United States. Almost all of the acquisitions (94.4\%) were made by developed economies, whereas emerging and developing countries (5.6\% in all) only had a marginal role (table 2 ). 
Tab. 2: Composition of the acquired mid-sized companies by acquirer's country of origin

\begin{tabular}{|c|c|c|}
\hline Acquirer's country & Number of acquisitions & $\%$ on total \\
\hline USA & 18 & 22.8 \\
\hline UK & 11 & 13.9 \\
\hline France & 9 & 11.4 \\
\hline Germany & 7 & 8.9 \\
\hline Holland & 6 & 7.6 \\
\hline Switzerland & 4 & 5.1 \\
\hline Sweden & 3 & 3.8 \\
\hline Austria & 2 & 2.5 \\
\hline Japan & 3 & 3.8 \\
\hline Spain & 3 & 3.8 \\
\hline Belgium & 3 & 3.8 \\
\hline Portugal & 2 & 2.5 \\
\hline Luxembourg & 1 & 1.3 \\
\hline Singapore & 1 & 1.3 \\
\hline China & 1 & 1.3 \\
\hline Ireland & 1 & 1.3 \\
\hline Finland & 1 & 1.3 \\
\hline India & 1 & 1.3 \\
\hline Ukraine & 1 & 1.3 \\
\hline Denmark & 1 & 1.3 \\
\hline Total & 79 & 100.0 \\
\hline
\end{tabular}

Source: Our elaboration on Mediobanca database

The 61 firms removed from the "observed database" present gaps in the budget series due to: merger (25 cases), winding up, bankruptcy, closure (15), double ownership change in the period concerned, namely restoring of the Italian leadership (14), new constitution (6), other reasons (4).

This group of firms represents the "observed database" under economicfinancial investigation here, as illustrated in Table 3.

Tab. 3: Chronological composition of "identified database" and "observed database"

\begin{tabular}{|c|c|c|c|}
\hline Acquisition year (t) & $\begin{array}{c}\text { "Identified" } \\
\text { companies (a) }\end{array}$ & $\begin{array}{c}\text { "Observed" } \\
\text { companies (b) }\end{array}$ & b / a (\%) \\
\hline 1999 & 11 & 4 & 36.4 \\
\hline 2000 & 10 & 6 & 60.0 \\
\hline 2001 & 14 & 7 & 50.0 \\
\hline 2002 & 9 & 5 & 55.6 \\
\hline 2003 & 7 & 8 & 71.4 \\
\hline 2004 & 7 & 4 & 57.1 \\
\hline 2005 & 13 & 9 & 69.2 \\
\hline 2006 & 16 & 12 & 75.0 \\
\hline 2007 & 22 & 11 & 50.0 \\
\hline 2008 & 26 & 13 & 50.0 \\
\hline 2009 & 8 & 3 & 37.5 \\
\hline TOTAL & 143 & 79 & 55.2 \\
\hline
\end{tabular}

Source: Our elaboration on Mediobanca database

\section{(1999-2009)}

Riccardo Resciniti Gabriele Barbaresco Giulio Maggiore

Michela Matarazzo

Foreign acquisitions of

Italian medium-sized companies from MNEs 


\section{sinergie} Vol. 33, N. 98, 2015
The budgets collected for the 79 firms, for which they were regularly available, amount to $79 \times 9=711$ units, according to the temporal distribution shown in table 4: it can be seen that the last year of foreign acquisition is limited to 2009 , so as to allow the analysis of the budget data concerning the follo wing four-year period, ending in 2013. The same table shows that the figures of $\mathrm{t}-4$ time refer to the years 1995-2005, those of t-3 time to 1996-2006 and so on until the period 2003-2013 of $t+4$ time. The years of crisis, that are after 2007, have gradually increased their effect from the $34.2 \%$ of the sample at base time $t+1$ to the $65.8 \%$ of $\mathrm{t}+4$ time.

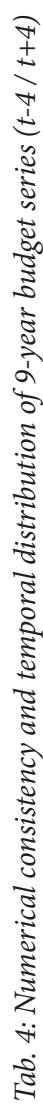

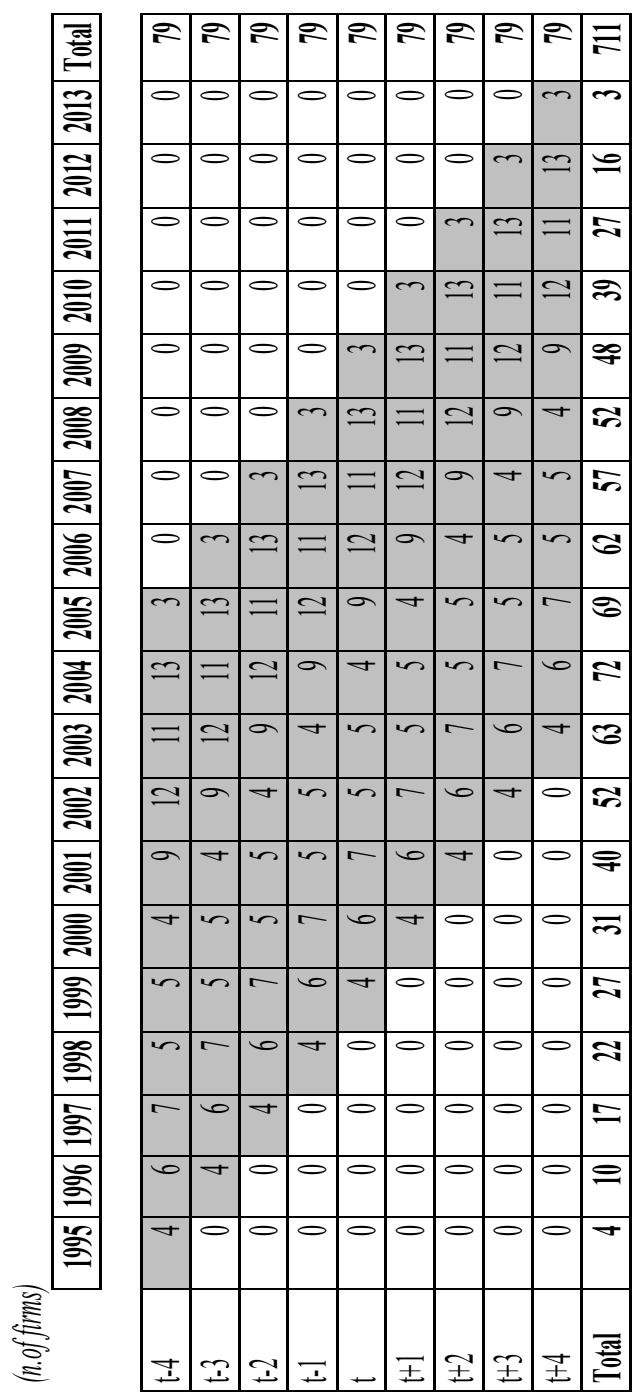

For each firm of the "observed database" and for their respective benchmarks, a set of budgetary indicators has been created for each year. 


\section{The future research}

Riccardo Resciniti

Gabriele Barbaresco

Giulio Maggiore

Michela Matarazzo

Foreign acquisitions of

Italian meclium-sized

Italian medium-sized
companies from MNEs

The question of whether it can be shown that the foreign-acquired firms really are superior in some respect to purely domestic firms is crucial, because apart from its direct effects, it has also indirect effects, in terms of externalities such as spillovers from the foreign affiliates to domestic firms.

Future research will try to understand: 1. whether acquisition targets present peculiar economic profiles before the ownership change; 2 . whether there are differences in the target-firm performance post-acquisition compared with purely domestic firms (non-acquired); 3 . and if so, how these effects differ within the group of acquired firms.

A great part of the most recent literature on cross border acquisitions has focused on the measurement of the acquired firms' performance in terms of labor productivity, wages, employment and profitability. The evidence from this literature suggests that the overall post-acquisition effects on performance achieved by foreign owned target firms are positive, but sometimes the results are contrasting. Furthermore, only few empirical studies have analyzed the impact of M\&As on the economic performance of SMEs, and no study has analyzed their impact on mid-sized firms, which is the focus of our paper. Accordingly, the following hypothesis is formulated:

H1: Cross border acquisitions positively affect the performance of target firms compared with purely domestic firms (non-acquired).

Consistently with what has been debated in literature, another research purpose (or purpose of research) is to find out specific operating and financial profiles in the firms acquired by foreign shareholders. Three possible pre-acquisition and three post-acquisition conditions are traced: positive performance, average performance and negative performance. Of course, each of the three conditions can be associated in different pre- and post-acquisition combinations. The purpose of the investigation is thus twofold: a) to establish whether the foreign subject is driven to investment by target firms with higher (cherry picking), lower (lemon picking) or undifferentiated performances.

Thus, the following hypothesis is formulated:

H2: The acquisition targets have higher performance before the ownership change compared with purely domestic firms.

Finally, another important issue linked to the topic of cross border acquisitions is that of cultural distance. Literature mainly suggests that the difficulties, costs, and risks associated with cross cultural contact increase with growing cultural differences between two individuals, groups, or organizations. Extensive empirical research on International Business has shown that cultural differences are negatively associated with M\&A performance. Accordingly, the following hypothesis is formulated:

H3: Firms acquired by EU multinationals show higher post-acquisition performance than firms acquired by non-EU multinationals compared with purely domestic firms. 
Sinergie Vol. 33, N. 98, 2015

The methodology

We will test the research hypotheses using peer analysis. This approach is appropriate for theory testing, because it was necessary to single out the effect related to the entry of foreign ownership.

The existence of significant differences in the indicators of the firms in the "observed database" and their respective benchmarks was assessed by comparing, for each indicator, the average values of the two groups in the whole time frame. The benchmark consists in the budget data of firms comparable to the target ones in terms of sales volume, belonging to the same industrial sector and the same region of location, but always under Italian ownership for the whole nine-year period. The range of benchmark firms is the same for all of the acquired firms (from EUR 15 to 100 million in the t year). Taking into account the intersection of 20 regions, 7 macrosectors and 11 time frames (for each $\mathrm{t}$ year of acquisition, from 1999 to 2009) of 9 years (from t- 4 to $t+4$ ), 62 comparison benchmarks were created for the 79 acquired firms, considering that in some cases they belong to the same mix of region and sector.

The time frame was divided into two periods: pre-acquisition years (from $\mathrm{t}-4$ to $\mathrm{t}$ included) and post-acquisition ones (from $\mathrm{t}+1$ to $\mathrm{t}+4$ ). After calculating the average value of each indicator in these two periods both for the target firms and their respective benchmark, the difference was worked out and the significance was assessed by an appropriate statistical test (Student's t-test), carried out for the two samples in a onetailed way, that is testing the significance of the average differences after having verified their sign. In a preliminary phase, a variance analysis was carried out in order to ascertain the homoscedasticity condition by Fisher's F-test. Since in most cases variances prove to be statistically different, the significance of the differences was assessed with the WelchSatterthwaite $t$-test for computing degrees of freedom. The same method was used for a further comparison of indicators, namely between their average value in each group (acquired and benchmark) in pre-acquisition years $(\mathrm{t}-4 / \mathrm{t})$ and their corresponding average value post-acquisition $(\mathrm{t}+1 / \mathrm{t}+4)$. Ultimately, the double comparison is meant to answer two separate questions: a) whether for each indicator a significant distance exists between the their differences in acquired and benchmark societies pre- and post-acquisition; b) whether a difference exists between the values of each indicator in the group of acquired societies and in those of benchmark ones pre- and post-acquisition (table 5).

Tab. 5: Test design for the ith indicator

\begin{tabular}{|l|l|l|}
\hline $\mathrm{t}-4 / \mathrm{t}$ & $\mathrm{t}+1 / \mathrm{t}+4$ & $\begin{array}{l}\text { One-tailed } \mathrm{t} \mathrm{Test} \mathrm{for} \\
\text { two samples (Welch- } \\
\text { Satterthwaite) }\end{array}$ \\
\hline Acquired ith indicator = A & Acquired ith indicator = B & $\begin{array}{l}\text { A-C } \\
\text { B-D }\end{array}$ \\
\hline Benchmark ith indicator = C & Benchmark ith indicator = D & $\begin{array}{l}\text { B-A } \\
\text { D-C }\end{array}$ \\
\hline
\end{tabular}

Source: Our elaboration 
The assessment procedure described above was based on the following indicators: productivity per employee (net added value per employee), labor cost per employee, number of employees and their composition ${ }^{3}$.

Further specifications have concerned the following aspects:

1. result differentiation based on the acquirer's activity: in this respect it was deemed appropriate to distinguish between industrial acquirers, irrespective of whether their activity is horizontal (acquirer and acquired firm belonging to the same link of the supply chain), vertical (customer or supplier relationship between acquirer and acquired firm), or of productive diversification, and financial acquirers (private equity funds above all). 63 of the acquirers concerned were industrial ones, whereas 16 were financial investors (see Table 5 for details on each indicator);

2. result differentiation based on the acquirer's origin: here we have distinguished between the European and non-European acquirer's seat. The case studies concerned are 44 European societies and 35 nonEuropean ones, mostly located in the English-speaking world (18 US cases and 11 UK cases) (see Table 5 again for details on each indicator).

In the analysis of the indicators (Table 6), considering the differentiation based on the acquirer's activity and country of origin, a comparison was carried out with the same statistical method between the period pre- and post-acquisition with respect to the average values of acquired societies belonging to each of the four sub-categories (European vs non-European; industrial vs financial) as well as with respect to the average values of their respective benchmarks.

Tab. 6: Analysis of the indicators acquirer's country of origin and activity

\begin{tabular}{|l|l|l|}
\hline $\mathrm{t}-4 / \mathrm{t}$ & $\mathrm{t}+1 / \mathrm{t}+4$ & $\begin{array}{l}\text { One-tailed t Test for two } \\
\text { samples (Welch-Satterthwaite) }\end{array}$ \\
\hline $\begin{array}{l}\text { European (Non-European) } \\
\text { acquired ith indicator = A }\end{array}$ & $\begin{array}{l}\text { European (Non-European) } \\
\text { acquired ith indicator = B }\end{array}$ & $\begin{array}{l}\text { A-C } \\
\text { B-D }\end{array}$ \\
$\begin{array}{l}\text { European (Non-European) } \\
\text { benchmark ith indicator = C }\end{array}$ & $\begin{array}{l}\text { European (Non-European) } \\
\text { benchmark ith indicator = D }\end{array}$ & $\begin{array}{l}\text { B-A } \\
\text { D-C }\end{array}$ \\
\hline $\begin{array}{l}\text { Industrial (Financial) } \\
\text { acquired ith indicator = A }\end{array}$ & $\begin{array}{l}\text { Industrial } \\
\text { acquired ith indicator = B }\end{array}$ & $\begin{array}{l}\text { A-C } \\
\text { B-D }\end{array}$ \\
$\begin{array}{l}\text { Industrial (Financial) } \\
\text { benchmark ith indicator = C }\end{array}$ & $\begin{array}{l}\text { Industrial (Financial) } \\
\text { benchmark ith indicator = D }\end{array}$ & B-A \\
\hline
\end{tabular}

Source: Our elaboration

\section{Conclusion}

Italy has witnessed a rapid increase in mergers and acquisitions, to the point of overcoming the EU 15 mean in the years 2008-2013 (with the

3 Of the excluded firms, 2 are common to 4 indicators, 3 were found outliers for 3 indicators, 7 for 2 indicators and the remaining 19 have outlier observations for one investigated indicator only.
Riccardo Resciniti Gabriele Barbaresco Giulio Maggiore Michela Matarazzo Foreign acquisitions of Italian medium-sized companies from MNEs 
sinergie Vol. 33, N. 98, 2015

exception of 2012) (UNCTAD, 2014). This study uses data from the Italian Mediobanca Research Department database for the first time in order to investigate this phenomenon for all the mid-sized companies, which carry remarkable economic weight within the Italian economy.

First results highlight that, in the observed period 1999-2009, 143 Italian firms were identified mainly coming from the engineering and the chemical-pharmaceutical sector. The dominance of these two sectors seems consistent with the fact that the foreign ownership in Italy has reached the highest levels of profitability and efficiency. It seems to be confirmed that MNEs are increasingly choosing an asset-seeking FDI, which consists in gaining access to competences and productive and commercial assets that are strongly present in Italian mid-sized companies. Out of the 143 acquired companies only 79 survived, while the remaining 61 are missing companies for the following reasons:

- merger (25 cases);

- winding up, bankruptcy, closure (15 cases);

- double ownership change in the period concerned, namely restoring of the Italian leadership (14 cases);

- new constitution (6 cases);

- other reasons (4 cases).

Further research will examine (at firms' level) for the first time the performance differences of all the mid-sized foreign-controlled firms, compared with the non-acquired ones, in the manufacturing sector. In particular, we will investigate the effects of cross border acquisitions on the performance of target firms in terms of labor productivity, employment, wages and profitability. However, the above mentioned missing companies ( $44,8 \%$ of the cases in the "identified database") poses a survivorship bias problem: cases of low profitability and downsizing in non-examined firms make it so that the evidence concerning the "observed database" would be positively distorted and not generalizable to its group as a whole. This problem, generally ignored by the literature as far as we know, is open to empirical qualitative analysis, which could also deliver interesting results and is thus also left for future research.

\section{References}

ANAND J., DELIOS A. (2002), "Absolute and Relative Resources as Determinants of International Acquisitions”, Strategic Management Journal, vol. 23, n. 2, pp. 119-134.

BALSVIK R., HALLER S.A. (2010), "Picking "Lemons" or Picking "Cherries"? Domestic and Foreign Acquisitions in Norwegian Manufacturing", The Scandinavian Journal of Economics, vol. 112, n. 2, pp. 361-387.

BERTRAND O., ZITOUNA H. (2008), "Domestic versus Cross-border Acquisitions: Which Impact on the Target Firms' Performance?", Applied Economics, vol. 40, n. 17, pp. 2221-2238.

CAVES R.E. (1996), Multinational Enterprise and Economic Analysis, Cambridge university press, Cambridge. 
CHARI A., CHEN W., DOMINGUEZ K.M.E. (2012), "Foreign Ownership and Firm Performance: Emerging Market Acquisitions in the United States", IMF Economic Review, vol. 60, n. 1, pp. 1-42.

CHEN W. (2011), “The Effect of Investor Origin on Firm Performance: Domestic and Foreign Direct Investment in the United States", Journal of International Economics, vol. 83, n. 2, pp. 219-228.

COLTORTI F., RESCINITI R., TUNISINI A., VARALDO R. (2013), Mid-sized Manufacturing Companies: The New Driver of Italian Competitiveness, Springer, Cham (ZG) Switzerland.

CONYON M.J., GIRMA S., THOMPSON S., WRIGHT P.W. (2002), “The Impact of Mergers and Acquisitions on Company Employment in the United Kingdom”, European Economic Review, vol. 46, n. 1, pp. 31-49.

DAMIJAN J.P., KONINGS J., POLANEC S. (2014), "Import Churning and Export Performance of Multi-product Firms", The World Economy, vol. 37, n. 11, pp. 1483-1506.

DEMIRBAG M., TATOGLU E., GLAISTER K.W. (2008), "Factors Affecting Perceptions of the Choice between Acquisition and Greenfield Entry: The Case of Western FDI in an Emerging Market", Management International Review, vol. 48, n. 1, pp. 5-38.

DESYLLAS P., HUGHES A. (2008), "Sourcing Technological Knowledge through Corporate Acquisition: Evidence from an International Sample of High Technology Firms", The Journal of High Technology Management Research, vol. 18, n. 2, pp. 157-172.

ENGELHARD J., NÄGELE J. (2003), “Organizational Learning in Subsidiaries of Multinational Companies in Russia”, Journal of World Business, vol. 38, n. 3, pp. 262-277.

GIRMA S., GÖRG H. (2007), "Evaluating the Foreign Ownership Wage Premium Using a Difference-in-Differences Matching Approach", Journal of International Economics, vol. 72, n.1, pp. 97-112.

GUISO L., (2014), "Risk Aversion and Financial Crisis”, EIEF Working Papers Series 1412, Einaudi Institute for Economics and Finance (EIEF), revised Dec 2014.

HARZING A.W. (2002), "Acquisitions Versus Greenfield Investments: International Strategy and Management of Entry Modes", Strategic Management Journal, vol. 23, n. 3, pp. 211-227.

HEYMAN F., SJÖHOLM F., TINGVALL P.G. (2007), "Is There Really a Foreign Ownership Wage Premium? Evidence from Matched Employer-Employee Data”, Journal of International Economics, vol. 73, n. 2, pp. 355-376.

HOPKINS H.D. (2002), "Cross-border Mergers and Acquisitions: Global and Regional Perspectives”, International Mergers and Acquisitions: A reader, pp. 86-115.

LUO Y. (1999), "Entry and Cooperative Strategies in International Business Expansion", Greenwood Publishing Group.

MATARAZZO M. (2012), Le strategie internazionali delle medie imprese. Modalità di entrata e nuovi mercati, Franco Angeli, Milano.

MCGUCKIN R.H., NGUYEN S.V. (2001), “The impact of ownership changes: A view from labor markets", International Journal of Industrial Organization, vol. 1, n. 5, pp. 739-762.
Riccardo Resciniti Gabriele Barbaresco Giulio Maggiore

Michela Matarazzo

Foreign acquisitions of

Italian medium-sized

companies from MNEs 
sinergie Vol. 33, N. 98, 2015

PISCITELLO L., RABBIOSI L. (2005), “The Impact of Inward FDI on Local Companies' Labour Productivity: Evidence from the Italian Case", International Journal of the Economics of Business, vol. 12, n. 1, pp. 35-51.

UNCTAD (2000), World Investment Report 2000, New York, United Nations.

UNCTAD (2014), World Investment Report 2014, New York and Geneva, United Nations.

WECHE GELÜBCKE J.P. (2013), “The Performance Of Foreign Affiliates in German Manufacturing: Evidence from a New Database", Review of World Economics, vol. 149, n. 1, pp. 151-182.

\section{Academic or professional position and contacts}

\section{Riccardo Resciniti}

Full Professor of Management

University of Sannio - Italy

e-mail: resciniti@unisannio.it

\section{Gabriele Barbaresco}

Head of Research Department

Mediobanca, Milano - Italy

e-mail: Gabriele.Barbaresco@mediobanca.com

\section{Giulio Maggiore}

Associate Professor of Management

Unitelma Sapienza, Roma - Italy

e-mail: giulio.maggiore@unitelma.it

\section{Michela Matarazzo}

Associate Professor of Management

Guglielmo Marconi University, Roma - Italy

e-mail:m.matarazzo@unimarconi.it

sinergie

italian journal of management

ISSN 0393-5108 DOI $10.7433 / \mathrm{s} 98.2015 .04$

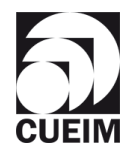

